\title{
Maer B. (Mike) Ozonoff, MD (1930-2019)
}

\author{
Maer B. Ozonoff ${ }^{1} \cdot$ Rebecca Stein-Wexler $^{1}$
}

Received: 11 June 2019 /Revised: 11 June 2019 / Accepted: 28 June 2019 / Published online: 25 July 2019

(C) Springer-Verlag GmbH Germany, part of Springer Nature 2019

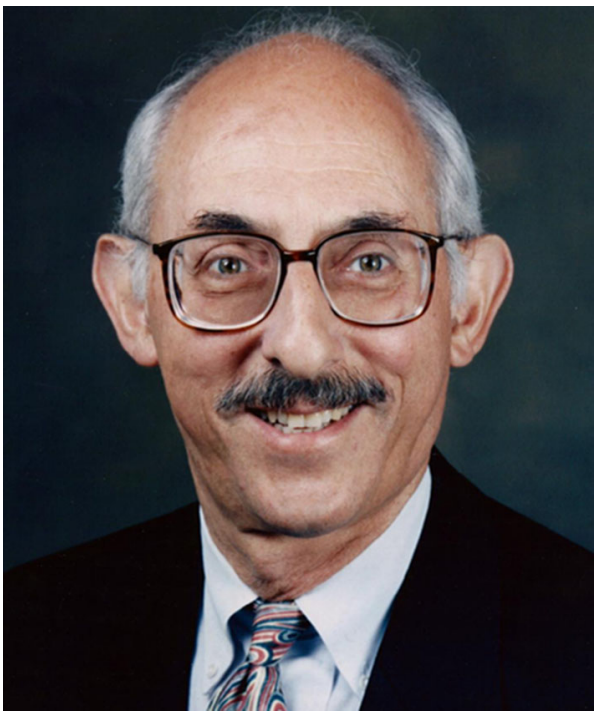

Maer B. (Mike) Ozonoff died May 11, 2019, after a long, happy, and fulfilling life, at the age of 89.

He was born, raised and educated in Milwaukee, WI. His Midwestern roots formed the platform of his attitudes toward life and his fellow citizens, despite his many moves. His mother was a schoolteacher who imbued in him a lifelong dedication to good grammar, careful scholarship and old-school manners. (Her background as a penmanship teacher, however, did not prove to be a genetic trait). His father was the prototypical old-time family doctor who made house calls day and night, 7 days a week. After his too early death, it was found that he never billed the one-third of his patients who were too

Maer B. Ozonoff contributed to this obituary prior to passing away.

Rebecca Stein-Wexler rsteinwexler@ucdavis.edu

1 Division of Pediatric Radiology, University of California Davis Medical Center and UC Davis Children's Hospital, 4860 Y St., Suite 3100, Sacramento, CA 95817, USA poor to pay during the Depression. As a young boy Mike often accompanied his father on home calls, sitting outside in the car rather than invading a family's privacy — not an easy feat in a cold Wisconsin winter. Mike decided to be a doctor at about age 5 .

He attended undergraduate and medical school at Northwestern University in Chicago. After service as a medical officer in the Navy, he moved west and trained in radiology at University of California, San Francisco (UCSF; where he met his wonderful wife-to-be), followed by a fellowship year in Stockholm and London to specialize in pediatric radiology. Although the majority of his professional life was spent on the East Coast, he and his family lived in northern California three separate times, the last 16 years in Davis.

Major events in his professional life included appointment as director of radiology at Newington (CT) Children's Hospital for 27 years and service on the active or volunteer university medical faculties of Yale School of Medicine, University of Connecticut, University of Utah, University of California Davis and University of California San Francisco. He served as president of the Society for Pediatric Radiology (SPR), developing the relationship between SPR and Springer-Verlag, Pediatric Radiology's publisher. He also served as distinguished scientist at the Registry of Radiologic Pathology in Washington, D.C.

$\mathrm{He}$ was a true leader in the fields of pediatric and musculoskeletal radiology. He brought brilliance and clarity to the many papers he authored - from the first he wrote as chief resident at UCSF, documenting the gradual appearance of several teeth in an ovarian teratoma, to the last, on scoliosis surgery as a risk factor for cholelithiasis. His papers were original, relevant and important. Some were humorous but pointed, such as an editorial he wrote toward the end of his career titled "Nondisease," begging the medical community to stop referring to eponymous developmental, traumatic and stress lesions as diseases (fortunately Ozonoff dysplasia of the hip is not termed a disease). As he concluded, "There is so much we do not know ... that we should not confuse matters we do understand." 
That comment exemplifies who he was: a humble, inspiring man with vast knowledge of pediatric orthopedic radiology; a man willing to spend evenings and weekends researching and writing his magnificent book, Pediatric Orthopedic Radiology — a book (with its subsequent editions) that would influence pediatric radiologists everywhere; a man who nurtured the careers of so many, encouraging young radiologists to blossom and grow; a man whose enthusiasm led others to join him in the fascinating world of pediatric radiology. He lectured widely, spending a year at the Armed Forces Institute of Pathology, traveling internationally to share his expertise, and finally, in retirement, giving talks to radiology residents at University of California Davis, the final beneficiaries of his wisdom.

These were the proud accomplishments of his profession, which he loved.

His medical life combined teaching and academic research interests with daily attention to his young patients, who, although yet children, displayed a constant optimism in the face of many medical challenges, making his career far more than a simple duty in his best attempts to help them.

But he balanced profound devotion to his profession with an even greater devotion to his family. The true highlights of his life were the years spent with his constantly supportive, loving and much loved wife and his dear family. He is survived by his wife, Carlene, four children, eight grandchildren, and his sister and brother.

\section{Compliance with ethical standards}

Conflicts of interest None

Publisher's note Springer Nature remains neutral with regard to jurisdictional claims in published maps and institutional affiliations. 